\author{
DAGMARA KORNOBIS-ROMANOWSKA \\ ORCID: 0000-0001-5860-0760 \\ Uniwersytet Wrocławski \\ Centrum Doskonałości Jeana Monneta \\ Katedra Badań i Studiów Europejskich im. Jeana Monneta \\ Katedra Prawa Międzynarodowego i Europejskiego
}

\title{
OBYWATELSTWO I PRAWA SPOŁECZNE UNII EUROPEJSKIEJ W DOBIE KRYZYSU GOSPODARCZO-POLITYCZNEGO
}

\begin{abstract}
Abstrakt: „Obywatelstwo”, „prawa socjalne” i „kryzys” to trzy hasła, które składają się na zagadnienie prawne niniejszego opracowania. Są to zarazem jedne z najbardziej palących problemów politycznych, prawnych i gospodarczych w Europie, aktualne nie tylko dzisiaj, lecz wręcz wpisane w integrację europejską przez wszystkie lata jej istnienia. O ile dziś można powiedzieć, że proces tworzenia wspólnego rynku oraz integracji gospodarczej zbliża się do rzeczywistego zakończenia, o tyle prawne uregulowanie obywatelstwa Unii nadal znajduje się w fazie rozwoju. Zmieniająca się na niekorzyść sytuacja polityczna i ekonomiczna w Europie doprowadziła do modyfikacji i zawężenia praw obywateli UE — od obywatelstwa rynkowego, przez społeczne, aż do polegania na doktrynie ,istoty praw” tylko w bardzo szczególnych i wyjątkowych okolicznościach. Z tego powodu, mimo że obywatelstwo unijne znajduje swoją bezpośrednią podstawę w prawie unijnym, w praktyce przekłada się ono raczej na status jednostki w danym państwie przyjmującym niż na jej formalną pozycję w UE. Dzisiaj więc, bardziej niż kiedykolwiek, obywatelstwo unijne wyraża się przede wszystkim w zaangażowaniu społecznym i wymaga czynnego uczestnictwa we Wspólnocie, czyniąc ją potrzebną i realną.
\end{abstract}

Słowa kluczowe: Unia Europejska, obywatelstwo, prawa społeczne, kryzys gospodarczy i polityczny

\section{WSTĘP}

Obywatelstwo, prawa socjalne i kryzys to hasła, z którymi związane są jednocześnie największe oczekiwania oraz największe rozczarowania we współczesnej Unii Europejskiej (UE). Punktem wyjścia przedstawionego opracowania jest teza, że o ile prawa obywatelskie i socjalne w UE są czynnikiem pogłębiającym integrację, o tyle kryzys gospodarczy prowadzi także do kryzysu politycznego we Wspólnocie. Na taką tezę pozwala przede wszystkim retrospekcja i przegląd po- 
stępu integracji oraz związku między sytuacją polityczną i gospodarczą a spójnością w UE od pierwszych lat jej istnienia. Od wejścia w życie traktatu rzymskiego minęły już sześćdziesiąt dwa lata ${ }^{1}$, a traktat $\mathrm{z}$ Maastricht, którym ustanowiono w Unii instytucję obywatelstwa europejskiego, wszedł w życie dwadzieścia siedem lat temu². Kryzys ekonomiczny osiągnął swój szczyt w 2009 roku i choć aktualnie trwa na rynku dobra koniunktura, to widmo ponownej recesji pojawia się już nad Europą i światem. Kolejny kryzys ma już jednak podłoże nie tylko gospodarcze, lecz także polityczne, wynikające z problemów migracyjnych, klimatycznych, obronnościowych, Brexitu czy kwestii związanych z tożsamością, praworządnością i wartościami.

Można powiedzieć, że aktualne kryzysy, których doświadcza Unia, są w dużej mierze następstwem znacznego zróżnicowania społeczeństw i podziałów scen politycznych w państwach członkowskich, a problemy wewnętrzne w poszczególnych krajach UE mają swoje skutki i są odczuwalne w całej Unii. Pomimo więc ponad sześćdziesięcioletniej historii, kolejnych traktatów, modyfikacji i stałego usprawniania współpracy krajów członkowskich w Unii nie udało się osiągnąć stanu równowagi, w którym wszyscy obywatele mieliby równe prawa i równe szanse. Przed Europą wciąż stoi wiele wyzwań, w tym nowych i niezwykle problematycznych. Wśród nich obywatelstwo i prawa socjalne to jedne z najbardziej palących kwestii, mają bowiem charakter podstawowy i dotyczą jednostek bezpośrednio. Społeczeństwo żywo i intensywnie reaguje na wszelkie zmiany w tym zakresie, a dostęp do świadczeń socjalnych dla obywateli jest skutecznym narzędziem polityki krajowej. $Z$ tego powodu zestawienie tych dwu czynników wobec kryzysu w państwach członkowskich i UE stanowi, z jednej strony, silny bodziec wpływający na poziom eurosceptycyzmu, z drugiej jednak, jeśli za punkt wyjścia przyjmiemy, że obywatele w państwach członkowskich oczekują od władz państwowych i ponadpaństwowych przede wszystkim bezpieczeństwa socjalnego, wolności gospodarczych i politycznych, to rozwój projektu określonego jako UE wydaje się najlepszym rozwiązaniem dla współczesnej Europy, zmagającej się nie tylko $\mathrm{z}$ wewnętrznymi problemami w państwach członkowskich, lecz także zdanej na konkurencję ze Stanami Zjednoczonymi i Chinami. Jaki jest obecnie kierunek, w którym zmierza UE, i jakie stanowisko w tej sprawie zdaje się dominujące w państwach członkowskich? Oto przedmiot zainteresowania tego opracowania.

1 Traktat ustanawiający Europejską Wspólnotę Gospodarczą z 1957 roku, w tej wersji obowiązywał od 1958 do 1993 roku; https://eur-lex.europa.eu/legal-content/FR/TXT/PDF/?uri=CELEX:11957E/ TXT\&from=PL (dostęp: 15.02.2020).

2 Art. 8 TUE w wersji traktatu z Maastricht (Dz.Urz. UE C 1992, 191/01). Więcej na ten temat zob. P.J. Neuvonen, Equal citizenship and its limits in EU Law: We the burden?, „Modern Studies in European Law" 2016, s. 32 n, https://www.bloomsburyprofessional.com/uk/equal-citizenship-and-itslimits-in-eu-law-9781782258179/ (dostęp: 15.02.2020).. 


\section{OD OBYWATELSTWA RYNKOWEGO DO OBYWATELSTWA SPOŁECZNEGO - OBYWATELSTWO UE JAKO ISTOTA UPRAWNIEŃ JEDNOSTKI}

Punktem wyjścia integracji europejskiej na podstawie traktatu rzymskiego było stworzenie wspólnoty gospodarczej, bez wyraźnej interakcji między swobodami rynkowymi a prawami podstawowymi i bez zezwolenia na odstępstwa od swobód rynkowych ${ }^{3}$. Już w pierwszych latach istnienia Wspólnot Europejskich Trybunał Sprawiedliwości, wówczas wspólnotowy, a dziś Unii Europejskiej (TSUE), wyraźnie jednak stwierdził, że

prawo wspólnotowe, niezależne od ustawodawstwa państw członkowskich, nie tylko nakłada na jednostki zobowiązania, lecz może również być źródłem uprawnień stanowiących element statusu prawnego tych jednostek ${ }^{4}$.

W odniesieniu do swobodnego przepływu pracowników i usług oraz swobody przedsiębiorczości Trybunał podkreślił, że te wolności o charakterze rynkowym „skutkują przyznaniem praw bezpośrednio wszystkim podmiotom”. W ten sposób TSUE w swoim orzecznictwie ustanowił więź między swobodami rynku wewnętrznego a prawami przysługującymi osobom prywatnym (tak zwanymi prawami podstawowymi), których przestrzeganie w ostatecznym bilansie jest miernikiem demokracji i praworządności ${ }^{6}$. W działalności orzeczniczej Trybunału $^{7}$ rozwinęła się wówczas kategoria zasad ogólnych prawa, których prawa podstawowe są częścią ${ }^{8}$, a rynek wewnętrzny i jego swobody zostały wyraźnie powiązane z prawami jednostki ${ }^{9}$. Na tym etapie można więc było mówić o obywatelstwie rynkowym, w wypadku którego prawa jednostek były ściśle połączone z działaniami o charakterze gospodarczym. Stan ten jednak szybko ewoluował, tak że w niedługim czasie to nie rynek określał zakres ochrony praw podstawowych, a odwrotnie.

3 S. O'Leary, The relationship between community citizenship and the protection of fundamental rights in community law, „Common Market Law Review” 32, 1995, nr 2, s. 519.

${ }^{4}$ Sprawa 26/62 Van Gend and Loos, EU:C:1993:1.

5 Sprawa 48-75 Royer, EU:C:1976:57, pkt 31.

6 Art. 2 TUE, stanowiący, że: „Unia opiera się na wartościach poszanowania godności osoby ludzkiej, wolności, demokracji, równości, państwa prawnego, jak również poszanowania praw człowieka, w tym praw osób należących do mniejszości. Wartości te są wspólne Państwom Członkowskim w społeczeństwie opartym na pluralizmie, niedyskryminacji, tolerancji, sprawiedliwości, solidarności oraz na równości kobiet i mężczyzn".

7 Sprawa 29/69 Stauder, EU:C:1969:57; 11/70 Internationale Handelsgesellschaft, EU:C:1970:114; 4/73 Nold, EU:C:1974:114.

${ }^{8} \mathrm{Na}$ podstawie art. 6 TUE; Traktat o Unii Europejskiej i Traktat o funkcjonowaniu Unii Europejskiej w wersji traktatu z Lizbony, wersja skonsolidowana (Dz.Urz. UE L 2016, 202/1).

9 M. Everson, The legacy of the market citizen, [w:] New Legal Dynamics of European Union, red. J. Shaw, G. More, New York 1995; G. de Búrca, The language of rights and European integration, [w:] New Legal Dynamics..., s. 29-30. 
Kierunek ten został utrzymany do dziś i w ciągu dziesięcioleci od traktatu rzymskiego coraz większy nacisk kładziono w Unii na ochronę praw podstawowych, zarówno w praktyce instytucji unijnych, jak i państw członkowskich ${ }^{10}$. Aktualnie można powiedzieć, że proces tworzenia wspólnego rynku oraz integracji gospodarczej zbliża się do rzeczywistego zakończenia, gdy tymczasem podstawa prawna obywatelstwa Unii nadal znajduje się w fazie rozwoju. Wyraźnie widać więc, że pierwotne założenia procesu integracji europejskiej zostały zmodyfikowane co do istoty i wciąż podlegają przemianom.

Początek dała im umowa międzynarodowa o charakterze gospodarczym, a następnie wątki gospodarcze zostały wzbogacone i rozpoczął się nieprzerwany proces, w którym Wspólnota skierowała się w stronę obywatelstwa, praw podstawowych, w tym politycznych i społecznych, oraz zakazu wszelkiej dyskryminacji. Podstawę prawną i punkt wyjścia stanowi art. 20(1) TfUE, który przewiduje, że

Ustanawia się obywatelstwo Unii. Obywatelem Unii jest każda osoba mająca obywatelstwo Państwa Członkowskiego. Obywatelstwo Unii ma charakter dodatkowy w stosunku do obywatelstwa krajowego, nie zastępując go jednak.

Traktat ściśle wiąże zatem obywatelstwo unijne z przynależnością do państwa członkowskiego. Trybunał Sprawiedliwości UE w swoim orzecznictwie potwierdził ten proces i orzekł, że z art. 20 TfUE wynika, że osoby fizyczne mają prawo mieszkać w innym państwie członkowskim tylko dlatego, że są obywatelami UE, a

status obywatela Unii ma stanowić podstawowy status obywateli państw członkowskich, pozwalający tym spośród nich, którzy znajdują się w takiej samej sytuacji, korzystać z takiego samego traktowania wobec prawa, bez względu na przynależność państwową i z zastrzeżeniem wyraźnie przewidzianych wyjątków ${ }^{11}$.

Warto podkreślić passus o zakazie wszelkiej dyskryminacji ze względu na przynależność państwową, co wyraźnie wynika zresztą z art. 18 TfUE, przewidzianego w ramach części II traktatu „Niedyskryminacja i obywatelstwo Unii”. Tym samym niedyskryminacja — obywatelstwo — swoboda przemieszczania się — aktywność zawodowa tworzą ciąg pojęć, którym UE ma służyć i je urzeczywistniać. Odzwierciedla to orzecznictwo TSUE, który uznał obywatelstwo UE za źródło prawa do swobodnego przemieszczania się ${ }^{12}$ oraz dalszych uprawnień powiązanych z działalnością zawodową, jak na przykład prawo wjazdu i prawo

10 Zob. takie dokumenty, jak: Wspólna deklaracja Rady, Parlamentu Europejskiego i Komisji z 1977 roku (Dz.Urz. C 1977, 103/1), preambuła Jednolitego Aktu Europejskiego z 1986 roku (Dz Urz. L 1987, 169/1), TUE w wersji traktatu z Maastricht oraz wersji traktatu z Lizbony, w szczególności na podstawie art. 6 TUE. Zob. także sprawy: 60,61/84 Cinéthèque, EU:C:195:329, pkt 26; C-260/89 Ellinki Radiophonia Tileorassi, EU:C:1991:254, pkt 41-42.

11 Zob. np. sprawy C-184/99 Grzelczyk, EU:C:2001:458, pkt 31; C-413/99 Baumbast, EU:C:2002:493, pkt 82; C-148/02 Carlos Garcia Avello, EU:C2003:539, pkt 22.

12 Sprawa C274/96 Bickel i Franz, EU:C:1998:563, pkt 15-16. 
do pozostania na terytorium państwa członkowskiego, prawo do podjęcia pracy, uruchomienia własnej działalności gospodarczej, sprowadzenia członków rodziny dowolnej narodowości, a także czynne i bierne prawo wyborcze w wyborach samorządowych i do Parlamentu Europejskiego czy opieki dyplomatycznej i konsularnej ${ }^{13}$. Uprawnienia wynikające $\mathrm{z}$ art. 20 TUE łączą się więc z uprawnieniami przewidzianymi $\mathrm{w}$ art. 45 TfUE, polegającymi na swobodzie przepływu pracowników wewnątrz UE, która obejmuje zniesienie wszelkiej dyskryminacji ze względu na przynależność państwową między pracownikami państw członkowskich w zakresie zatrudnienia, wynagradzania i innych warunków pracy (art. 45(1) i (2) TfUE). Co istotne, ogólny zakaz dyskryminacji ze względu na przynależność państwową zgodnie $\mathrm{z}$ art. 18 TfUE dotyczy także obywateli UE biernych zawodowo ${ }^{14}$, z zastrzeżeniem, że postanowienia traktatu dotyczące niedyskryminacji i równego traktowania nie mają zastosowania do tak zwanych sytuacji czysto wewnętrznych, w których nie ma czynnika łączącego je z którąkolwiek z sytuacji przewidzianych przez prawo unijne ${ }^{15}$.

$\mathrm{Na}$ tym tle idea obywatelstwa w Unii Europejskiej jawi się jako nowa kategoria - idea obywatelstwa społecznego, którą należy uznać za kolejny, bardziej zaawansowany etap integracji. Prawa socjalne są bowiem bardzo ważne dla współczesnego państwa prawa. Mogą stanowić solidną podstawę koncepcji rządzenia w całej Unii za pomocą polityki bardziej zorientowanej na człowieka ${ }^{16}$, opartej na gwarancjach obywatelstwa i niedyskryminacji. Jest to wizja obywatelstwa ponadnarodowego ${ }^{17}$, bazującego wprost na traktatach unijnych i niezwiązanego z wolnościami jednolitego rynku, a mającego realizować cele integracyjne. Obywatelstwo określa w niej status integracji społecznej jednostki, wytyczając dla niej zakres prawa pobytu i do pomocy socjalnej. Co istotne, obywatelstwo w takim rozumieniu - jako podstawowy status osób, wobec których normy ponadnarodowego porządku prawnego są bezpośrednio skuteczne - nie jest związane ze swobodami rynkowymi i jako takie dotyczy wszystkich osób, w tym tych nieaktywnych ekonomicznie.

13 Art. 20(2) TUE.

14 Więcej na ten temat zob. D. Thym, The elusive limits of solidarity: Residence rights of and social benefits for economically inactive Union citizens, „Common Market Law Review” 52, 2015, nr 1, s. 17-25.

15 Sytuacje, do których prawo UE nie ma zastosowania, podlegają regulacjom krajowym, przede wszystkim krajowemu prawu konstytucyjnemu.

${ }^{16}$ Postulat budowania Unii jako coraz ściślejszego związku między narodami Europy, w którym decyzje podejmowane są z możliwie najwyższym poszanowaniem zasady otwartości i jak najbliżej obywateli, zgodnie z art. 1 TUE.

17 Zob. sprawy: C-85/96 Martinez Sala, EU:C: 1998:184/99; C-184/99 Grzelczyk, EU:C: 2001:458; Trojani, EU:C:2004:488. 


\section{OBYWATELSTWO JAKO PODSTAWOWY, ALE WARUNKOWY STATUS OBYWATELI PAŃSTW CZŁONKOWSKICH}

Idea obywatelstwa społecznego w Unii z początku zdawała się z powodzeniem zastępować dobrze ugruntowane obywatelstwo rynkowe. Szczególnie atrakcyjna była w czasach dobrobytu oraz stabilnej sytuacji politycznej, gospodarczej i finansowej. Obecnie mamy jednak do czynienia z fragmentaryzacją, rozdrobnieniem i niestabilnością gospodarczą. W ostatnich latach zmienił się ponadto klimat polityczny. Jesteśmy świadkami silnych nastrojów antyeuropejskich z powodu światowego kryzysu i towarzyszących mu oczekiwań migrujących obywateli UE o świadczenia społeczne w innych państwach członkowskich. Oczekiwania te często mają niestety charakter roszczeniowy i są przejawem tak zwanej turystyki socjalnej.

Okoliczności te doprowadziły do pojawienia się nowych elementów rozpoznanych w orzecznictwie TSUE. Podstawą prawną dla tej linii orzeczniczej jest zasada niedyskryminacji oraz ograniczenia i warunki przewidziane w prawie wtórnym UE, co ciekawe - z pominięciem wszelkich odniesień do norm traktatowych. Skargi do TSUE dotyczące równego traktowania rozpatrywane są więc wyłącznie na podstawie dyrektywy 2004/38 w sprawie prawa obywateli Unii i członków ich rodzin do swobodnego przemieszczania się i pobytu na terytorium państw członkowskich ${ }^{18}$. Tak wytyczone ramy prawne pozwoliły, by Trybunał doprecyzował tezę, że „obywatelstwo Unii powinno stanowić podstawowy status obywateli państw członkowskich” o kolejny passus: „gdy korzystają oni z prawa do swobodnego przemieszczania się i pobytu"19. Tym samym na podstawie powołanej dyrektywy Trybunał przyznał, że zasada zakazu dyskryminacji w UE nie jest nieograniczona i nie ma zastosowania do wszystkich obywateli UE w tej samej sytuacji. Narodowość nie uprawnia koniecznie do korzyści wynikających z obywatelstwa, przeciwnie — państwa członkowskie mogą wprowadzać różne traktowanie obcych obywateli, biorąc pod uwagę nie tylko formalne prawo pobytu przez okres dłuższy niż trzy miesiące, lecz także dodatkowe wymagania. Wśród nich można wskazać stopień zintegrowania społecznego i gospodarczego czy wkład do krajowych systemów ochrony socjalnej. W tym celu bierze się pod uwagę długość pobytu, intensywność poszukiwania pracy oraz więzi osobiste i powiązania rodzinne w państwie przyjmującym. Decydującym kryterium w tej mierze jest zatem faktyczna więź ekonomiczna obywatela z państwem przyjmującym, która uzasadnia możliwość ograniczenia zakresu beneficjentów wsparcia socjalnego, aby osiągnąć cel gospodarczy. W tym celu

18 Art. 7(1)b, art. 14 dyrektywy 2004/38/WE Parlamentu Europejskiego i Rady z dnia 29 kwietnia 2004 roku w sprawie prawa obywateli Unii i członków ich rodzin do swobodnego przemieszczania się i pobytu na terytorium Państw Członkowskich, zmieniająca rozporządzenie (EWG) nr 1612/68 i uchylająca dyrektywy 64/221/EWG, 68/360/EWG, 72/194/EWG, 73/148/EWG, 75/34/ EWG, 75/35/EWG, 90/364/EWG, 90/365/EWG i 93/96/EWG (Dz.Urz. L 158, 30/04/2004, s. 77123).

19 Sprawa C274/96 Bickel i Franz. 
dopuszczalne jest zastosowanie przez państwo przyjmujące kryterium, które stanowi dowód stopnia integracji obywatela z lokalnym społeczeństwem. Jak podkreśla TSUE w swoim orzecznictwie, wymóg minimalnego poziomu integracji zapewnia państwom członkowskim uzasadniony sposób uniknięcia nieuzasadnionego obciążenia finansowego ${ }^{20}$, które mogłoby mieć konsekwencje dla całego systemu pomocy, jaka może zostać przyznana przez to państwo. Warto zauważyć w tym aspekcie inny ważny element, stanowiący novum $\mathrm{w}$ tych postępowaniach, mianowicie mniej zindywidualizowane, a bardziej ekonomiczne podejście do osób ubiegających się o świadczenia społeczne.

Z takiego ukształtowania sytuacji prawnej obywateli UE wynika jasny wniosek, że relacje w takim układzie jak wskazany powyżej muszą być zrównoważone. Narzędziem służącym do równoważenia interesów w UE jest zasada proporcjonalności ${ }^{21}$, zgodnie z którą środek jest proporcjonalny, jeżeli nie nakłada ograniczenia większego niż to konieczne do nadania obciążeniu finansowemu rozsądnych granic. Przy dokonywaniu takiej oceny niezbędne jest rozważenie alternatywnych, mniej restrykcyjnych środków, przy uwzględnieniu takich nadrzędnych zasad, jak efektywność administracyjna, pewność prawa czy transparencja, które muszą być brane pod uwagę przy porównywaniu preferowanego środka z narzędziami alternatywnymi. Dzięki nim musi zostać zapewniona równowaga między unijną zasadą solidarności ${ }^{22}$ a krajową zasadą solidarności społecznej. O ile bowiem lojalność wobec Unii wymaga od państw członkowskich zaangażowania i aktywnego podejmowania wszelkich środków ogólnych lub szczególnych, właściwych dla zapewnienia wykonania zobowiązań wynikających z traktatów lub aktów instytucji Unii, o tyle solidarność społeczna w wymiarze krajowym jest postawą pasywną i obronną, uwzględniającą także aspekt finansowy działań państwa członkowskiego.

Taka postawa wymaga zatrzymania się i rozwagi, dlatego w tym ujęciu prawo socjalne UE powinno stać się również częścią wyważonej, standaryzowanej praktyki w państwach członkowskich, z zaangażowaniem ich organów administracji i sądów krajowych, podobnie jak ma to miejsce w kontekście rynku wewnętrznego. Uwidaczniają się tu zadania i rola władz krajowych w państwach członkowskich w wypracowywaniu stałej praktyki i spójnego orzecznictwa dotyczącego uznawania świadczeń z tytułu ochrony socjalnej, przewidzianych w ustawodawstwie krajowym. Jest to podejście „krok po kroku”, mające na celu sukcesywne budowanie zrównoważonych relacji między unijnym prawem socjalnym a prawem krajowym w państwach członkowskich. Należy bowiem pamiętać, że obywatelstwo UE, jako komplementarne wobec obywatelstwa krajowego, kształtowane jest w pierwszej kolejności w procesie legislacyjnym w państwach członkowskich. To do państw członkowskich należy zatem funkcja ustawodawcza w zakresie budowania statu-

20 Sprawy połączone C-523/11 i C-585/11 Laurence Prinz, EU:C:2013:524, pkt 36. Zob. także opinia rzecznik generalnej E. Sharpston w tej sprawie, EU:C:2013:90.

21 Art. 5(4) TUE.

22 Art. 4(3) TUE. 
su obywatela Unii, one też w głównej mierze są odpowiedzialne za skuteczność uprawnień wyprowadzanych przez obywateli z prawa unijnego.

\section{JAKI JEST SCENARIUSZ NA PRZYSZŁOŚĆ?}

Jean Monnet, ojciec integracji europejskiej, powiedział kiedyś, że „Ludzie działają tylko w stanie konieczności i zwykle uznają konieczność tylko w sytuacji kryzysowej" 23 . Dziś, kiedy Europa jest wciąż w kryzysie, funkcjonowanie jednolitego rynku jest ponownie w centrum europejskiego projektu i staje się główną racją bytu dla Unii złożonej z dwudziestu siedmiu państw członkowskich. Dalsze losy integracji zależą od zdolności i gotowości tych państw do przyjęcia wspólnych polityk i standardów, przy czym istnieje wiele rozwiązań.

Komisja Europejska opracowała pięć scenariuszy, które zostały przedstawione w Białej księdze w sprawie przyszłości Europy ${ }^{24}$. Biała księga nie inicjuje przy tym konkretnych działań legislacyjnych ani instytucjonalnych, jest za to dokumentem mającym raczej skłonić do przemyśleń i dyskusji o Unii do 2025 roku. Punktem wyjścia poszczególnych scenariuszy jest założenie, że dwadzieścia siedem państw członkowskich nadal tworzy Unię, a kolejne rozwiązania opierają się na pierwszym założeniu utrzymania status quo, poprzez zmianę zakresu i priorytetów, po częściowy lub zbiorowy skok naprzód. Poszczególne scenariusze w wielu miejscach się pokrywają, nie wykluczają się zatem wzajemnie ani nie są wyczerpujące.

Ich założenia, pokrótce rzecz ujmując, przedstawiają się następująco:

— scenariusz pierwszy — zakładający kontynuację, przewiduje, że Unia będzie nadal się koncentrować na zapewnianiu zatrudnienia, wzrostu gospodarczego i inwestycji poprzez wzmocnienie jednolitego rynku i zwiększenie inwestycji w infrastrukturę cyfrową, transportową i energetyczną;

— scenariusz drugi — przewiduje stopniową koncentrację Unii na jednolitym rynku wobec tego, że nie uda się osiągnąć konsensusu w wielu dziedzinach polityki, takich jak migracja, bezpieczeństwo, obronność;

— scenariusz trzeci — zakłada „koalicję chętnych” i to, że możliwa będzie ściślejsza współpraca między konkretnymi państwami członkowskimi, ale tylko w wybranych dziedzinach, w tym na przykład w sprawach socjalnych;

— scenariusz czwarty — przyjmuje, że UE-27 zintensyfikuje swoje działania w takich dziedzinach, jak innowacja, handel, bezpieczeństwo, migracja, zarzą-

23 „Men only act in a state of necessity and usually only recognize necessity in a situation of crisis" - Filozofia i wybór z piśmiennictwa Jeana Monneta w: Proceedings of Centenary Symposium organized by the Commission of the European Communities, Jean Monnet, Brussels, 10.10.1988, Luxembourg 1989, s. 127, http://aei.pitt.edu/52373/1/A7287.pdf (dostęp: 15.02.2020).

${ }^{24}$ Komisja Europejska, COM(2017)2025 z 1.03.2017, https://ec.europa.eu/commission/future-europe/white-paper-future-europe-and-way-forward_pl (dostęp: 15.02.2020). 
dzanie granicami i obronność. Jednolity rynek w nowych kluczowych obszarach zostanie pogłębiony;

— scenariusz piąty — ostatni i najbardziej optymistyczny, przyjmuje, że Unia decyduje się robić wspólnie znacznie więcej we wszystkich obszarach polityki.

Przedstawione przez Komisję Europejską założenia są więc na największym poziomie ogólności. Zostały omówione w sposób neutralny, zobiektywizowany, można by rzec - niezaangażowany. Tymczasem, nazywając rzecz po imieniu, chodzi tu o przyszłość organizacji międzynarodowej, jaką jest UE. Stawką jest utrzymanie jedności budowanej w Europie przez ponad sześć dekad, z osiągnięciami w postaci autonomicznego systemu prawnego, którego podmiotami są nie tylko państwa, lecz także ich obywatele. Co więcej, na szali jest przestrzeń wolności, bezpieczeństwa i sprawiedliwości w poszanowaniu praw podstawowych oraz różnych systemów i tradycji prawnych państw członkowskich, z której korzystają nie tylko obywatele UE, ale też obywatele państw trzecich i bezpaństwow$\mathrm{cy}^{25}$, dzięki temu, że nie ma kontroli osób na granicach wewnętrznych, a polityka w dziedzinie azylu, imigracji i kontroli granic zewnętrznych jest dla państw członkowskich wspólna, oparta na solidarności i sprawiedliwości.

Jedno jest pewne - Unia jest w kryzysie, chyba największym w historii. Zmaga się z coraz większą frustracją i obawami wielu osób, związanymi z niepewną przyszłością polityczną, chwiejną sytuacją gospodarczą, bezrobociem, narastającymi nierównościami i brakiem możliwości, zwłaszcza dla ludzi młodych. $Z$ pewnością bardzo odważnym stwierdzeniem są cytowane słowa Jeana Monneta, że kryzys mobilizuje do twórczego działania i zmusza do rozwiązywania problemów egzystencjalnych. Paradoksalnie jednak może właśnie wraz z nim pojawia się szansa na naprawę negatywnych konsekwencji populistycznych rządów w niektórych państwach członkowskich, w tym w Polsce. Tą szansą jest wzmocnienie fundamentów Unii: obywatelstwa, praw podstawowych, demokracji i rządów prawa.

\section{ZAKOŃCZENIE}

Na przestrzeni lat i w historii Unii obywatelstwo UE było tą instytucją, której rozwój niewątpliwie doprowadził do stworzenia nowej wspólnej przestrzeni prawnej i społecznej. W ramach tej przestrzeni doszło do rekonstrukcji i rekonfiguracji koncepcji integracji, demokracji, praworządności. Spójna ochrona praw obywateli UE jako podstawy Wspólnoty zawsze była i pozostaje jednym z priorytetowych celów Unii, również w czasie kryzysu. Zmieniająca się na niekorzyść sytuacja polityczna i ekonomiczna w Europie doprowadziła jednak do zawężenia praw obywateli UE, od obywatelstwa rynkowego, przez społeczne, aż do polegania na doktrynie ,istoty praw” tylko w bardzo szczególnych i wyjątkowych okoliczno-

\footnotetext{
25 Art. 67(2) TfUE.
} 
ściach. Obecnie można zauważyć, że główna podstawa interpretacji uprawnień unijnych wynikających z obywatelstwa nie znajduje już oparcia w postanowieniach traktatu o UE, ale bazuje na dosłownym i raczej wąskim brzmieniu aktów prawa stanowionego przez instytucje UE (rozporządzenie, dyrektywa). Pomoc socjalna może być zatem uzależniona od stopnia integracji jednostki ze społeczeństwem, z państwem, w którym żyje. Obywatele Unii, którzy przeprowadzają się do innego państwa członkowskiego, lecz nie podejmują tam pracy ani jej nie poszukują, muszą się liczyć z jej odmową. Pomimo więc, że obywatelstwo unijne znajduje swoją podstawę w prawie unijnym, to jednak w praktyce przekłada się ono raczej na status jednostki w danym państwie przyjmującym niż na jej formalną pozycję w UE. Dzisiaj jednak, bardziej niż kiedykolwiek, obywatelstwo polega na czynnym uczestnictwie we Wspólnocie.

Taka konstrukcja obywatelstwa jest następstwem wyraźnie pragmatycznego podejścia państw członkowskich, które jest jak najbardziej zrozumiałe w trudnych ekonomicznie czasach. Podejście to wywołało jednak sporą niepewność prawną u stron krajowych postępowań sądowych i administracyjnych w bardzo delikatnych sprawach dotyczących imigracji, pobytu i statusu osobistego. Przyszłość dla migrujących obywateli Unii przedstawia się zatem niepewnie, gdyż w obliczu bessy bardzo trudno o warunki życia w poczuciu bezpieczeństwa socjalnego i sprawiedliwości społecznej. Do tego wciąż jeszcze pod znakiem zapytania pozostaje polityczna przyszłość niektórych państw członkowskich UE, w tym Polski. Nie niesie to $\mathrm{z}$ sobą niestety dobrej prognozy dla społeczeństwa $\mathrm{w}$ tych krajach, a przez to także dla UE.

Może warto, tytułem ostatecznej konkluzji, odpowiedzieć sobie na pytanie, o co toczy się ta gra. Otóż toczy się ona o tożsamość europejską i poczucie przynależności do realnej Wspólnoty. Alternatywa wydaje się w tym wypadku jasna: albo poszanowanie i promowanie wartości europejskich wśród obywateli państw członkowskich, którzy powinni rozumieć i rozumnie korzystać z obywatelstwa UE, albo pogłębianie aktualnych tendencji w obniżaniu poziomu demokracji, praworządności i praw podstawowych. I wybór wcale nie jest przesądzony, nawet przy założeniu, że kryzys gospodarczy zostanie przezwyciężony. Najtrudniej jest bowiem przezwyciężyć kryzys polityczny.

\title{
CITIZENSHIP AND SOCIAL RIGHTS OF THE EUROPEAN UNION IN THE CURRENT ECONOMIC AND POLITICAL CRISIS
}

\author{
Summary
}

Citizenship, social rights and crisis are the three phrases that appear with the legal issue presented in this paper. They are also one of the most pressing social, legal, and economic problems in the European Union, valid not only today, and inherent for European integration throughout all the years of its existence. 
Today, it may be concluded that the process of creating a common market is coming to an end, while the institution of Union citizenship is still in a state of constant change. The political and economic situation in Europe has led to a narrowing of the rights of EU citizens, from market citizenship, via social citizenship, to the reliance on the doctrine of the "essence of rights" only in very special and exceptional circumstances. Therefore, despite the fact that EU citizenship finds its basis in EU law, it results in practice in the status of the individual in the given host country rather than in its formal position in the EU. However today, more than ever, citizenship of the EU consists of active participation in the community, since the European community is real.

Keywords: European Union, citizenship, social rights, economic and political crisis

\section{BIBLIOGRAFIA}

Biała księga w sprawie przyszłości Europy, Komisja Europejska, COM(2017)2025 z 1.03.2017, https://ec.europa.eu/commission/future-europe/white-paper-future-europe-and-way-forward_pl. Dyrektywa 2004/38/WE Parlamentu Europejskiego i Rady z dnia 29 kwietnia 2004 roku w sprawie prawa obywateli Unii i członków ich rodzin do swobodnego przemieszczania się i pobytu na terytorium Państw Członkowskich, zmieniająca rozporządzenie (EWG) nr 1612/68 i uchylająca dyrektywy 64/221/EWG, 68/360/EWG, 72/194/EWG, 73/148/EWG, 75/34/EWG, 75/35/ EWG, 90/364/EWG, 90/365/EWG i 93/96/EWG (Dz.Urz. L 158, 30/04/2004, s. 77-123).

Jednolity Akt Europejski (Dz.Urz. L 1987, 169/1).

Neuvonen P.J., Equal citizenship and its limits in EU law: We the burden?, „Modern Studies in European Law" 2016.

New Legal Dynamics of European Union, red. J. Shaw, G. More, New York 1995.

O'Leary S., The relationship between community citizenship and the protection of fundamental rights in community law, „Common Market Law Review” 32, 1995, nr 2.

Proceedings of Centenary Symposium organized by the Commission of the European Communities, Jean Monnet, Brussels, 10.10.1988, Luxembourg 1989, s. 127, http://aei.pitt.edu/52373/1/ A7287.pdf (dostęp: 15.2.2020).

Thym D., The elusive limits of solidarity: Residence rights of and social benefits for economically inactive Union citizens, „Common Market Law Review” 52, 2015, nr 1.

Traktat rzymski, ustanawiający Europejską Wspólnotę Gospodarczą, https://eur-lex.europa.eu/legal-content/FR/TXT/PDF/?uri=CELEX:11957E/TXT\&from=PL.

Traktat o Unii Europejskiej w wersji traktatu z Maastricht (Dz.Urz. UE C 1992, 191/01).

Traktat o Unii Europejskiej i Traktat o funkcjonowaniu Unii Europejskiej w wersji traktatu z Lizbony, wersja skonsolidowana (Dz.Urz. UE L 2016, 202/1).

Wspólna deklaracja Rady, Parlamentu Europejskiego i Komisji z 1977 roku (Dz.Urz. C 1977, $103 / 1)$. 